\title{
The politics of genealogical incorporation: ethnic difference, genetic relatedness and national belonging
}

\author{
Catherine Nash
}

To cite this article: Catherine Nash (2016): The politics of genealogical incorporation: ethnic difference, genetic relatedness and national belonging, Ethnic and Racial Studies, DOI: $\underline{10.1080 / 01419870.2016 .1242763}$

To link to this article:

http://dx.doi.org/10.1080/01419870.2016.1242763

On the $17^{\text {th }}$ of April 2014 the Irish parliament's Joint Committee of Justice, Defence and Equality published a report calling on the state to officially recognize Irish Travellers as an ethnic group (Houses of the Oireachtas 2014). Their recognition as an indigenous nomadic minority ethnic group has long been recommended by international human rights organizations and is central to Irish Traveller campaigns for Traveller-appropriate public policy in the face of entrenched institutional discrimination especially in relation to housing, policing and education and deeply anti-Traveller attitudes (The Equality Authority 2006; Moore 2012; McVeigh 2007a, 2007b; O'Connell 2006). The recommendation of the report has not been accepted. In November 2015 a Sinn Féin motion in favour of the implementation of the recommendations of the report was undermined by an amendment which edited out the reference to state recognition of Traveller ethnicity (Hughes 2015; O'Halloran 2015).

This recommendation and its rejection reflects the ambiguity of the state's approach to the status of Travellers, and, indeed, of what counts as recognition. ${ }^{1}$ Resistance to official recognition predominates but policy is more equivocal. The rationale for not formally recognising Traveller ethnicity while funding anti-racism, anti-discrimination, and Traveller welfare and inclusion strategies, is that Travellers are already served by existing legislation. They 'have the same civil and political rights as other citizens under the Constitution' and Irish legislation giving effect to EU and international protections for ethnic minorities 'explicitly protects Travellers.', Since 2006 the Irish census includes the category 'Irish Traveller' as an option to the question 'What is your ethnic or cultural background?'. The inclusion of 'cultural 
background' in this question accommodates the contradictions of the state's refusal to officially recognize Irish Traveller ethnicity, while effectively treating Travellers as an ethnic group, albeit within dominant discourses of Traveller deviance, widespread antagonism to the idea of Traveller ethnicity, and political anxiety about the fiscal and electoral costs of granting official recognition. While there is some public and political support for recognition, deep antagonism to claims about the cultural and ancestral distinctiveness of Travellers persists.

This question of recognition is clearly not only a matter of legal rights, important as they are, but also of the deep symbolic significance of explicitly acknowledging the integrity, validity and value of Irish Traveller culture. Given the relatively straightforward approach of the Irish state to the status of new ethnic minority groups, it is the degree and historical depth of the cultural and genealogical distinctiveness of Irish Travellers as indigenous yet different from the majority population which are crucial in claims about ethnicity and resistance to these claims. Travellers do not challenge the territorial integrity of the state but the limits to the tolerance of difference in the nation. This is the political context of recent genetic studies of the origins of Irish Travellers as a distinct group.

Focusing on a high profile and award winning television documentary, Blood of the Travellers (2011), ${ }^{3}$ this paper explores the premises and implications of genetic investigations which seek to test degrees of genealogical relatedness between what is known as the settled or majority population and a minority group whose difference is simultaneously demonized and denied. This is not only a matter of the effects of the results for an ethnic group but of how human genomics is shaped by and contributes to debates about what counts as ethnicity and is thus worthy of recognition. Furthermore, I argue that the conventional model of the ethnic nation as a community of shared descent in which those who are not part of that genealogical community have no natural place in the nation, needs to be considered, not only in relation to exclusionary discourses of difference based on non-relatedness, but also in relation to the politics of genealogical incorporation. By this I mean the implications of locating groups within a national family tree in ways that may produce an inclusive social imaginary of shared descent but simultaneously deny ethnic difference and naturalize a genealogical calculus of national belonging. Addressing this here means first considering how groups or 'populations' of many kinds - racial, national, ethnic - are 
produced as legally recognizable subjects, collectives and objects of research through technologies of governance and genomics.

\section{Technologies of recognition}

The contradictory approach of the Irish state to Traveller ethnicity reflects tensions within the liberal governance of ethnic difference. The state is ideally impartial in granting and protecting equal rights to citizens irrespective of difference, and bound by national and extrajudicial - in this case EU and UN - requirements to address the position of ethnic minority groups, including nomadic minorities (O'Connell 2006; Moore 2004). But in practice this 'impartiality' is inflected by the imaginaries of the ethnic nation which privilege the majority culture and restrict meaningful public space for ethnic difference (Hall 2000). Though no longer overtly assimilationist, government policy responses to the so-called Irish Traveller 'problem' have progressively made it impossible, and ultimately illegal, to maintain the nomadic lifestyle around a circuit of traditional stopping points that is at the heart of Traveller culture (Crowley 2005; Helleiner 2000; Mulcahy 2011; Norris and Winston 2005; Fanning 2002; 2008). Efforts to empower Travellers through a model of active citizenship and democratic participation, promote respect for Traveller culture, and 'accommodating' Traveller mobility through the provision of transient sites since the late 1990 s, have been severely compromised by local authority failure to provide sites and by legislation that further criminalized traveller mobility (Crowley and Kitchin 2007). A model of consultation, participation and rights to protection against discrimination in exchange for compliance with the law and sedentary norms 'enables the government to regulate and limit Travellers' mobility and coerce settlement while being seen to be acting in ways that are consonant with liberal democratic ideals' (Crowley and Kitchin 2007, 142). It is these liberal multicultural principles of inclusion of ethnic minority groups, equity and respect for diversity that are also increasingly incorporated into the practice of human genomics.

Conventional ethnic, racial and national categories continue to shape how human genetic variation is researched, analyzed and described (Bolnick 2009; Fullwiley 2007; Fujimura et al, 2014; Reardon 2007). Yet, as Jenny Reardon argues, the genomic constitution of human groups is shaped by recent efforts to recast the field as ethical and democratic rather than ethically suspect (especially with regard to race and colonialism) through attending to the inclusion of minority ethnic groups and 
an emphasis on the informed and free participation and agency of research subjects. However, as Reardon argues, 'genome scientists do not produce knowledge about human beings who come pre-ordered into clear groups; rather they participate in the processes that decide which human collectivities can be recognized and understood' $(2012,34)$. Indeed, genomic ethics and ethnicity, or, to paraphrase Reardon (2012, 27), what comes to count as ethical and what comes to count as ethnic, can be understood as co-produced.

This is central to what Amy Hinterberger describes as 'emergent molecular multiculturalisms', in which large scale population-based biomedical studies gain public legitimacy through taking on the "political logics of institutionalized multiculturalism' $(2012,218)$ in which addressing the discrimination or disadvantage of groups requires their counting and monitoring. The incorporation of ethnically identified research subjects as donors of genetic material, can have the effect of presenting culturally identified groups as genetically distinctive and identifiable, as well as 'biomedically significant' $(2012,221)$. This is also the case when the demographic histories of ethnic groups, and especially those groups deemed to be in need of new technologies for reconstructing their ancestral pasts because of histories of subjugation, are the focus of genomic investigation and are targeted in the marketing of genetic ancestry tests. Paradoxically, as Reardon argues, the liberal ideal of an impartial but ethical science being progressively applied to explore collective origins and identity 'inhibits accounting for the material and symbolic conditions that shape genomic exploration of human origins and identity' $(2012,39-40)$ and may, in fact, create the conditions for new biological renderings of race, nation and ethnicity.

The question of how ancestry and collective identity are figured within genomic biohistories (Sommer 2010) of national or ethnic groups is crucial here. The scientists involved do not argue that ethnicity is genetic in a deterministic sense, or that ethnic identity maps neatly onto patterns of genetic variation, but do assume that an ethnic group's ancestral history can be known via genomics (Marks 2001). Genetic distinctiveness is seen as a measure of genealogical distance from other groups; degrees of genetic similarity are seen to reflect degrees of shared ancestry; shared ancestry is figured as a natural dimension of shared identity. In this way human genomics is a cultural practice that is embedded in and marked by wider western genealogical imaginaries, including those of ethnicity and ethnic nationhood (Zerubavel 2012). If sharing distinctive ancestry, evident in patterns of genetic 
variation, is taken to be fundamental to group identity, what might genomic investigations of ancestry mean both for questions of ethnic recognition and the genealogical incorporation of ethnic difference within the national community of shared descent?

\section{Irish biohistories}

Blood of the Travellers is structured through former Olympic boxer, national and Traveller hero, Francie Barrett's personal 'quest to find an answer' to the question of Irish Traveller origins. He facilitates the gathering of blood samples from Travellers for genetic analysis, in order, as the opening voiceover explains, 'to get an answer to his question and to understand the history of his people' with new 'tools of DNA technology'. The aim is to decide between accounts that Irish Travellers are 'related to Romany Gypsies or some other ethnic group that arrived in Ireland over the past one thousand years,' or 'have been a community here long before the arrival of the Celts,' or are 'settled Irish people that took to the roads during times of famine and eviction'. Geneticists Jim Wilson and Gianpeiro Cavelleri, who explain the science, oversee the analysis and deliver the results in the documentary are prominent in public and commercial initiatives using new genetic technologies in Ireland and the UK. Their work exemplifies the public and privately funded and commercially applied science of ethnically specific and national biohistories.

In the Irish context this includes studies of genetic variation across Ireland, and in relation to wider patterns of variation in the British Isles and continental Europe, and the genomics of diasporic origins and descent for individuals or groups using genetic ancestry tests to establish genetic histories and geographies of origin in Ireland (Nash 2008). Each strand involves practices of comparison, differentiation and definition. The meaning of individual test results or patterns of variation of groups are always derived comparatively in relation to others, whether in a diasporic clan name project, or in studies of what is defined as the 'indigenous' Irish population. Research on the pattern of variation of a specific sub-national group is necessarily conducted in relation to the wider population since making sense of genetic variation is a comparative process of exploring degrees of similarity and difference, and thus degrees of genealogical relatedness between groups at different scales and resolutions. 
The definition of a suitable research subject is always also a matter of 'common sense' as well as scientific sense about who counts as Irish. This is a 'common sense' of genealogical indigeneity both within studies of patterns of variation in the country and in the recent sequencing of a nationally representative 'Irish genome' (Tong et al 2010). The explanation of whose genome was sequenced in 2010 to produce the first Irish genome was that:

The genomic DNA used in this study was obtained from a healthy, anonymous male of self-reported Irish Caucasian ethnicity of at least three generations, who had been genotyped and included in previous association and population studies. These studies have shown this individual to be a suitable genetic representative of the Irish population (Tong et al 2010,2).

There is an unproblematised association between genealogy, genetics and a national biological citizen-subject here and in the wider evocation of national collective ancestry and origins that are made newly knowable through genomics (Nash 2014; 2015). Who is deemed to be a 'suitable genetic representative of the Irish population' is bound up with the persistent potency of the idea of a native national community sharing ancestry and descent from an original ancient people. Ideas of shared descent and socio-cultural and religious homogeneity that came to dominate Irish anticolonial nationalism in the early twentieth century have shaped attitudes to social groups defined as outsiders in Ireland: Jews, Protestants, Travellers, and since the late twentieth century, immigrant groups. A genealogical model of nationhood that defines those who settled in Ireland since the early modern period, and especially from Scotland and England, as outside a natural and national Catholic community of descent from ancient Gaelic Ireland, continues to haunt 'post-conflict' Northern Ireland and 'multicultural' Ireland. It is reflected in the late-twentieth-century creation of an Ulster Scots origin story of descent from the original inhabitants of Ulster and thus a counter-narrative of Protestant indigeneity in Northern Ireland (Nic Craith 2002).

In Ireland ideas of ancestral connection to an original people persist, differentiating between the 'indigenous Irish' and 'non-nationals', a term that has come to stand for 'all non-Irish others' (Fanning 2007, 22; Fanning and Mutwarasibo, 2007). This genealogical model of belonging gained more legislative purchase in 
2004 when, with majority public support, the Irish constitution was amended to remove the automatic right of citizenship from 'future generations of Irish-born children who could not demonstrate generations of belonging to the state' (Mullally 2007, 36). As Mullally $(2007,38)$ notes: 'no such steps were taken, however, to impose restrictions on the much larger category of [non-resident] persons entitled to acquire citizenship by descent under Irish citizenship laws'. Rights to citizenship for those born in Ireland now rely on a familial or genealogical connection to those already encompassed with the community of 'nationals' rather than birth alone. This model of native descent, difference and genealogical belonging shapes the ways in which Irish travellers have been positioned and position themselves in relation to the national community.

Aggressive antipathy towards Travellers has been interpreted as evidence of an ideology of ethnic and racial exclusiveness that dominated the foundation and early decades of the state and continues today (McVeigh 2007a, 2007b). As an affront to the anxious respectability, conservatism and normative sedentarism of the state, and evading the localized structures of church and state power, Travellers were deemed to be socially and culturally aberrant (Mac Laughlin 1998; 1999). Travellers have been racialized outsiders in Irish society (Fanning 2002; 2008). However, it is less clear whether this is a form of racialization that depends on understanding Travellers as genealogically alien and outside a national community of shared descent rather than socially or cultural alien. Underpinning the persistent demonization of Irish Travellers is their characterization as a deviant strand of the national community failing to adhere to its norms, rather than necessarily as a foreign intrusion. Refusing ethnic recognition facilitates discourses of Traveller 'reform' since social difference can be criticized but ethnic difference must 'respected'. Ancestral relatedness can thus be the basis for both differentiating degrees of belonging and for a homogenizing genealogical incorporation. The results of genetic investigations of degrees of genealogical relatedness between Travellers and settled people may therefore be incorporated into contradictory perspectives on the question of ethnic difference within the nation.

Traveller ethnicity is not set against national identity as Irish in Blood of the Travellers. It opens with Francie Barrett's dream of going to the 1996 Olympics as a way of achieving respect for himself and for Irish Travellers, and his deep pride in carrying the Irish flag at the opening ceremony 'not only for Travellers but for my 
country'. The footage of being greeted on his return by President Mary Robinson replays a symbolic gesture of national inclusion. This opening foregrounds its emphasis on Traveller culture as part of and distinctive within Irish society, Traveller identity as both Irish and Irish Traveller, and its celebration of Traveller achievement despite long and deep discrimination. It also stands for wider claims about the validity of being both Irish and ethnically distinctive in Ireland. Nor does the campaign for ethnic recognition entail any claim for preferential treatment as an indigenous minority over other ethnic groups. The use of the term 'indigenous nomadic minority' signals the longevity of presence of a minority group distinct from, but not in competition with, new immigrant minorities.

However, this does not mean that accounts of 'who was here first' and timing of the arrival or emergence of Travellers as a distinct group do not matter given the continued power of ideas of genealogical and indigenous belonging. The documentary includes a Traveller discussion of different origin stories which reflect wider popular theories as well as the influence of recent genetic studies of Roma origins (Ní Shuinéar 1994): as linked to Romany Gypsies and through them to India; as nomadic since the Famine; or in existence as a distinctive community of culture and descent before then. Others speculate that Travellers may descend from an original pre-Celtic population, who subsequently adopted old Gaelic surnames and thus are "the genuine Irish' - 'more genuinely Irish than an awful lot of the settled population' - or the 'first people who arrived here' thus challenging the assumption of external origins of Travellers in relation to a settled majority indigenous group, or their simple and very recent derivation from that indigenous majority. For Barrett the genetic study 'might show that we were the first people here and the settled community came from the Traveller community rather than the other way around'. Genetic accounts of Traveller origins clearly need to be understood in relation to the continued potency of a genealogical model of native belonging in Irish ethnic nationalism. I consider this first by addressing the ideas of lack that frame the genetic project in Blood of the Travellers, and secondly by addressing what genetic accounts of commonality and difference imply for the politics of recognition and inclusion.

\section{Genetic history for the 'forgotten ones'}

The genetic project in Blood of the Travellers is, in part at least, a device through which to present an unusually critical account of deeply anti-Traveller attitudes and 
policies and unusually positive representations of Traveller culture and traditions. This is a feature of the film making of Sean McGrath. ${ }^{4}$ The concerns expressed in it about the absence of a conventionally documented Traveller history and intergenerational transfer of Traveller culture and identity are tied to directly politicized articulations of the effect of discrimination on Traveller identity and culture and a profound challenge to what counts as the collective Irish past. The crisis of identity that features in the documentary is not presented as internal to Irish Travellers but as a product of longstanding, systematic and worsening social and institutional discrimination. The term 'forgotten ones' used by Barrett points to the longstanding scholarly as well as social and institutional disavowal of Traveller ethnicity, which is only recently being addressed by academic research about Irish Traveller history and traditions, including the Irish Traveller language, Cant or Gammon. This is presented as not only a matter of concern for Travellers but for Irish society more widely. Patrick Nevin of the organization Travellers for Travellers argues in the documentary: 'it is not just important to us as Travellers, it is important to the histories of the people of Ireland'. Irish Traveller history and culture is protrayed as part of the collective Irish past and not just the Irish Traveller past.

The value of a verified account of historical origins and the longevity of Irish Traveller existence as a nomadic community in Ireland is presented not only in terms of the significance of collective self-knowledge but very directly in terms of its political importance in challenging the entrenched denial of Traveller ethnicity and asserting rights to a Traveller way of life. Key to this is disputing the common argument that Irish Travellers descend from impoverished people who became nomadic as the result of the Famine of the 1840 s, which has justified assimilationist policies and the disparagement of Traveller nomadism as the product of degradation (Ní Shuinéar 1994; 2004). Early in the documentary Michael McDonagh, manager of Meath Travellers Workshops presents what is at stake in claims about Famine origins:

The thinking and concept that Travellers only came about at the time of the Famine is quite dangerous because you see them as damaged or broken country people that need to be fixed and repaired. And if you try to make people into something they are not you damage them. But if you have to think the Travellers have history, have heritage then you replace the word assimilation with words like celebration and that changes the attitude 
completely. Most people and most Travellers don't understand their history and that's quite sad.

Establishing the longevity of Travellers as a group that predates the Famine is crucial to the claims of long established ethnic distinctiveness.

The genetic investigation is heavily framed by ideas of lack of knowledge of Traveller origins, and this is fundamental to the way in which genomic science is figured as redemptive and therapeutic for social groups whose knowledge of ancestry and origins has been erased through violence, displacement and subjugation (Nelson 2016). This is intensified by a focus on Barrett's efforts to find out about his own family's past. The sources are conventional ones and deeply affecting: photographs, oral narrative, archives and civil records. But the genetic analysis is depicted as a new and more sophisticated way of addressing this lack and loss. An oversimplified model of the elitist nature of archival and documented history is evoked by Wilson to suggest the democratising as well as mystery solving capabilities of science.

However, reactions to the documentary reflect not only the power and authority of science, but also resistance to the figuring of a collective lack that needs to be filled by science, and the implication that other forms of historical knowledge such as oral history lack credibility. The emphasis on the absence of written history disregards the significance of storytelling in Traveller culture, published folk histories and biographies (Fanning 2008, 15), and recent efforts to record oral histories (Ó hAodha 2009; Walsh 2009). As Aoife Breathnach (2007) has argued, the difficulty of verifying the historical emergence of Travellers should not be equated with an unknown history. Brigid Quilligan, then Director of the Irish Traveller Movement, expressed her, her family's and wider Traveller approval of the documentary, especially in contrast to other media representations. But for her it validated rather than supplied an otherwise unknown history:

Now there is one programme [...] Blood of the Travellers. Personally it is the only programme that I approved of and it is the only programme my family approved of. [...] Now I don't ever want to get into this DNA debate around Travellers in terms of proving our identity. We know who we are. We might not have a written down history because history has been written for us. By the way, everything you read about Travellers is BS. It is written 
for us by Settled People. We predated the Famine. We know that because we have ancestors belonging to us buried in America prior to the Famine. So we know we were nomadic around Ireland before that. There's references in history to us as well. And if you look at the traditional nomadic stopping spots around Ireland, they are absolutely centuries old. And there is stuff there you know in terms of photographs, and in terms of stories and songs that we know have been passed down through generations. And the songs and story telling make reference to history even if our history is not written in books. So we know the time of the Famine and that comes out in our song, in our traditional songs, it comes out in our story telling. Anything recorded in history, while we didn't write it down. It's oral. So we know about it. So our history has been recorded. (In conversation with Brigid Quilligan, 11 March 2014).

She insists on Traveller history as recorded and known even if not in a conventional documented sense and, implicitly, its value and authority in spite of the appeal of scientific evidence. But if the genetic analysis appeals as a validation of a history that predates the Famine it not assumed to be an unproblematic resource:

In terms of Blood of the Travellers, I liked the fact that people were looking at their DNA and being able to trace it back. Now, there are huge questions around it and I am no expert, or even any kind of expert on DNA, but for me it was validation. We know that we didn't just drop off, you know, two hundred years ago. We know we were here for a lot longer (Brigid Quilligan, 11 March 2014).

Even if her reference to 'lack of expertise' reflects the asymmetrical authority, status and power of science over oral culture, her comment that 'there are huge questions around it' suggests a much more equivocal place for genetics in the politics of Irish Traveller ethnicity than unambiguous support, and its complex implications for belonging in Ireland as Irish Traveller. In what follows I consider those 'huge questions' via the documentary's closing scene where Francie Barrett is told a genetic account of Traveller origins and difference and his place within it. 


\section{Genetic commonality and difference}

There are four scenes of Traveller men being told the results of the analysis of their genetic material in Blood of the Travellers. In each case Jim Wilson stands in front of a large map of the world telling them and the family members of their ancestral lines and origins, including allusions to ancient Gaelic royal blood to help amplify the drama of the revelations. However, the genetic figuring of Traveller difference and relatedness is most explicit in the closing scene when Barratt's results and those of the wider study are announced. This scene is of Francie Barrett on his sofa with his family's children being told the results by Jim Wilson. Gianpiero Cavelleri sits nearby. This is what Wilson says and how Barrett responds:

JW: So Francis, finally we get to tell you where your ancestry comes from. We have looked at all of your genome to try to have an estimate of all of your ancestry. Where does it all come from and indeed where does the ancestry of all of the Travellers come from. And the way we did this was to look at a lot of different markers scattered through all of your genes not just one little part but looking across all of your different genes. And we compared these with a database we have of a hundred populations we have across the world, many from Europe and many other places. Using this we could see that the Irish Travellers' closest relatives were the settled Irish. But, they differed and were distinct from the settled Irish and occupy their own cluster. So the Irish Travellers cluster together. It means that they're genetically close to one another; they are genetically related. They form a community. And the settled Irish are also a community, near to one another, related to one another but at the same time distinct. They overlapped to some degree but they were also distinct to some degree. And you were right in the middle of the cluster. Right in the middle of the Travellers' cluster. So...

FB: I was right in the middle...

JW: you were right in the middle. So what we saw was that people who were Irish Travellers who have for instance a grandmother who was settled, or perhaps one of their parents was settled, they were forming the overlap between the two communities. So if we try to think what we have worked out from this whole process, we can tell a number of things. The first is that all Travellers don't descend from one man or one woman. Actually the Traveller sample was 
just almost as diverse as the settled Irish sample. So it showed there were multiple people who founded, who began the Irish Traveller community. So that is the first thing to be sure of. The second was that we saw absolutely no sign of any connection to the Roma Gypsies, the Gypsies who live in continental Europe, because they are very distinct and in fact have an origin in India originally. The third thing we could look at was whether there was any sign of the Travellers having arisen at the time of the Famine. And I think there is no way that this was possible. We see quite significant differences between the Irish Travellers and the settled Irish and there is no way that in five generations that this difference could be set up.

FB: Yeah, yeah.

JW: The next theory that people have put forward is that the travelling started around about the time of Cromwell. Let's say around 1600 or so. And I think that it is older than that. That there is too much of a distinction for that to be. I think that the Irish Travellers have an origin before the time of Cromwell even though there has definitely been some marriage between the communities in the meantime.

The scene then shifts to Wilson talking to camera alone and then back again to the scene with Barrett and his family. Shaking hands with Wilson, Barrett says:

Very good, very good. You did an absolutely fabulous job. I am glad with myself. At the end of the day I am an Irish man, but I'm stuck in the middle of the whole lot as usual. [Laughs]. Brilliant, absolutely brilliant.

There the programme ends.

This account of Irish Traveller origins corresponds to other recent studies that suggest that there is no evidence that they originate through the arrival of a continental nomadic group (Relethford and Crawford, 2013; North, Martin and Crawford, 2000, see also Crawford and Relethford 1974). At one broad resolution Irish Travellers do not have a pattern of genetic variation that is different to the pattern of variation for the rest of the population. However, at a finer resolution they are found to have a distinct pattern within that broad similarity. This suggests that though they share ancient origins with the rest of the population they have also been 
socially distinctive and largely endogamous within their group for many hundreds of years - 1000 to 2000 is Wilson's estimate - which can be seen in distinctive patterns of variation. The analysis of genetic variation cannot provide an explanation for this, and so cannot produce the origin story it seemed to promise. Instead the results suggest that Travellers are both similar too, and different from, the settled population; sharing ancient ancestry but also having distinctive ancestry because of that social distance.

The political implications of this account of common and distinct ancestry partly lie in where the emphasis falls on commonality and difference and how they are interpreted in arguments about Traveller ethnicity. The account of shared indigenous ancestry undermines the definition of Travellers as not native and thus as demonized outsiders, genetically as well as culturally and socially, in an old politics of national purity. However, definitively different origins could serve their figuring as a protected minority within a newer politics of multicultural rights and recognition. Being genetically like the settled population could suggest that Travellers are part of the Irish people and thus should not be demonized. Alternatively, accounts of genetic similarity could be taken to suggest that they are 'like everyone else and thus should behave like everyone else'. The 'problem' of Travellers is understood in terms of their social and cultural difference rather than genetic difference.

The response of one prominent politician to the Oireachtas recommendation, reported in the Irish Independent, indicates how questions of Traveller status are entwined with both longstanding and new configurations of belonging and not belonging in Ireland. It was reported that:

the recommendation was welcomed by the Irish Traveller Movement, which said it consolidates more firmly the importance of acknowledging Travellers' outstanding human, legal and cultural rights. But Fine Gael TD Charlie Flanagan said that, although he is pro-Traveller, he disagrees with the recommendation. The Fine Gael parliamentary chairman said he found the argument put forward by the committee as 'less than persuasive'. 'I believe Travellers are Irish like the rest of us - no better, no worse,' he said. Mr Flanagan said the Central Statistics Office has already identified 10 different ethnic groups in the country. "Do we now accord special ethnic status to 
Protestants, Jews and people from Connemara? I think this is more political correctness than Traveller rights", he said (Sheahan, 2014).

The seeming inclusiveness of the statement that 'Travellers are Irish like the rest of us' is a refusal of Traveller cultural difference, but it is also articulated in relation to a new 'excess' of immigrant ethnicity and in resistance to the further multiplication of ethnic categories. Protestants and Jews are identified as traditional 'outsiders' but not in need of ethnic recognition in order to undermine the argument for Traveller ethnic recognition. The reference to 'people from Connemara' suggests that Traveller ethnic recognition is as spurious as a regional identity being defined as ethnicity. The genealogical incorporation of Travellers into the national community implies that cultural difference alone is not enough to justify the designation as ethnic. This suggests an understanding of ethnicity that is implicitly genealogical; ethnicity must be something more than cultural difference.

Other critical reactions reiterate this illiberal denial of cultural difference, but with added scientific support. One Irish Times online commentator posted this response:

I wonder if the 'travellers' know that they have the same DNA as the majority of other Irish people??? Which means that they aren't a minority just because they choose to live a different lifestyle and evade paying taxes yet expect the rest of the hard working public to give them handouts, ridiculous. $^{5}$

Rather than a model of commonality and equality countering racism or xenophobia, the insistence on sameness here is a symbolic erasure that refuses ethnic difference while demonizing this form of social difference. Furthermore, it closes down the possibility of multiple identities as Irish and as ethnically distinct not just for Travellers but for all in Ireland. It is especially fitting then that Francie Barrett should have the last word in the documentary, since for him the results confirm his own model of identity that allows for both commonality and similarity, and difference and distinction, as an Irish man and as an Irish Traveller.

Other pro-Traveller commentators have seen the results as lending support to the case for official recognition of Traveller ethnicity. They were mentioned in one of 
the hearings of the Irish government committee that produced the report and recommendation of the recognition of Traveller ethnicity (Houses of the Oireachtas 2014, appendix 4 11), but not taken up for discussion and have not become part of Traveller political discourses, perhaps because of a reluctance to cede authority to science and awareness of its risks. This includes the danger of making an account of genetic distinctiveness, and thus genealogical relatedness, the basis for ethnicity in contrast to conventional historical sources, oral histories and cultural practice. Though ethnicity is commonly partly defined in terms of shared ancestry, genetic studies of this kind imply a much more rigid equation of ethnic identity, group membership, and genetic and genealogical relatedness.

In the state's management of claims to rights or benefits based on ethnic particularity, genealogical and genetic distinctiveness may seem to offer a strong basis for defining and delimiting ethnic minority status. But this can become a divisive criteria for membership in that ethnic group, raising difficult and damaging issues of differentiating between authentic and inauthentic claims to membership (TallBear 2010). Wilson talks of those with settled as well as Traveller ancestry being positioned genetically between the Traveller cluster and the settled cluster, as genetically intermediate between them. Genomic studies of Irish Travellers may appear to support the recognition of Traveller ethnicity but at the same time they could undermine the group membership of some Traveller families or individuals on the basis of their difference from those defined as within the Traveller cluster. It figures the heterogeneity of the Traveller 'community' according to degrees of difference from the 'unmixed'.

This genetic differentiation is potentially divisive given that intermarriage between Travellers and settled people is relatively commonplace and since it is not unusual for Traveller family histories to contain non-Traveller ancestors. It is also damaging if genetic distinctiveness, which depends on historically low levels of intermarriage that produce that distinctiveness, is taken to be an index of cultural and social separation. This is a risk that Brigid Quilligan recognizes:

And I personally am very interested in that and would love to have my DNA tested. But I would be half afraid that I'd come back and they'd tell me actually you're a settled person. Because people do intermarry, you know, 
throughout the generations. And you don't know who you are (Brigid

Quilligan, 11 March 2014).

There are moments in the depiction of Barrett's family history in the documentary that suggest the problematic effects of a geneticized genealogical reckoning of belonging, indigeneity, authenticity and purity of descent. He comments that his grandfather is thought to have been a settled man but that his name suggests he was part of a Traveller circus family. In another scene he is comforted by surname expert Nollaig Ó Muraíle who informs him though this name, unlike most Traveller surnames, is not an ancient aristocratic and even royal Gaelic name, it is an AngloNorman name from Mayo in the thirteen century and so qualifies as a native Irish name. Indigeneity is extended here but in relation to the model of the nation's original Gaelic people, and alongside his differentiation from other Travellers. Barrett turns out to be located definitively as Traveller according to the genetic analysis, but the personal risk of undermining an individual sense of identity and producing differentiated degrees of collective belonging is clear given the emphasis on genealogical belonging in the minority group as well as in the nation.

\section{Conclusion}

The social value of liberal genomics is frequently presented in terms of how its accounts of shared human origins and of relatedness between groups who have historically been in conflict challenge ethno-nationalist or racial divisions. However, this genetic exploration of Traveller origins - albeit within an otherwise progressive portrayal of Traveller culture and agency and critical account of Traveller oppression - exemplifies the ethical limits of its typical approaches to ethnicity. As this case shows, liberal genomics reifies ethnic groups as genealogical communities of shared descent and applies a logic of genetic differentiation to these heterogeneous social collectives. This project does not crudely suggest a single genetic profile for all Travellers, but has made it possible for individuals to be described in relation to patterns of variation associated with Travellers and those associated with the settled population. Since there is no place in a genomic model of ancestry for all the creativity of kinship - in which relatedness and identity are understood as both in some sense given (culturally and biologically) and socially made - genomic accounts like this subject flexible and practiced collective identities to tighter, neater and more 
rigid reckonings of inclusion and difference. A language of genetic variation, rather than purity, can still be used to describe individuals as outside a community of shared descent.

But genealogical incorporation also has exclusionary and divisive effects. Describing Travellers as a distinctive branch on the national family tree appears to be inclusive but it reinforces the idea of the nation as a natural genealogical community. Though the account of genetic distinctiveness and deeper shared ancestry in this case may support a model of ethnic distinctiveness and shared Irishness, this implies that the potential incorporation of Travellers within the ethnic nation as an ethnically distinct group is based on an underlying degree of genealogical and genetic similarity. Describing Irish Travellers as genetically distinct may serve the case for recognition of ethnicity. However, extending genetic criteria for collective identity from a minority ethnic group to the so called 'majority' population produces the idea of a national population - the Irish - as genetically distinct and genetically defined and the nation as a community of shared descent. Including Irish Travellers as an ancestrally related but genealogically distinct group within the Irish population allows for the inclusion of one sort of difference. But figuring the settled population as a genealogical community only allows for some and not other sorts of ethnic groups to be encompassed within the nation. Travellers can potentially be symbolically incorporated as a distinctive branch of the national family tree but other groups those of recent immigrant migrant origin - have no place upon it and thus are always outsiders in this national imaginary. The implication is that Travellers cannot be ethnic since they are not sufficiently different genealogically; immigrant ethnic groups cannot be national because they are too genealogically different.

This suggests an understanding of ethnicity as defined by an unspecified but necessary degree of genealogical difference and, implicitly, different geographical origins, whether or not these are racially marked. This can be seen at work in the Irish government's insistence on a model of ethnicity in which an ethnic group must be genealogically as well as culturally distinct from the majority population. A double imperative of fulfilling the multicultural duty of addressing the place of ethnic minorities in the state but containing multicultural duties and demands underlies the Irish government's claims that Travellers are in practice treated as an ethnic group under existing legislation and, at the same time, its resistance to the recognition of Traveller ethnicity. The insistence on shared descent in this case is a specific refusal 
of Traveller ethnic difference and wider resistance to the potential multiplication of ethnic categories and claims. The argument that 'we are all related' can be deployed at the scale of the nation to deny ethnic difference if it is not grounded in genealogical and thus genetic difference, as well as exclude the 'non-native'. The state's criteria for ethnic recognition and discourses of national incorporation thus both work through a genealogical logic. Genealogical imaginaries of collective identity are being rearticulated via genomics in complex and often apparently progressive ways, but their continued risks can be seen in the homogenizing and exclusionary effects of genealogical incorporation.

\footnotetext{
${ }^{1}$ Is it reported that granting recognition would not entail a constitutional change. It would involve the Taoiseach and Minister for Justice making a statement to the Dáil, ${ }^{2}$ Traveller and Roma Inclusion Unit of the Department of Equality and Justice: http://www.travellerinclusion.ie/website/TravPolicy/travinclusionweb.nsf/page/travell er_\&_roma_communities_in_ireland-en (accessed 3 July 2015).

${ }^{3}$ This two-part documentary, directed and produced by Liam McGrath (Scratch Films, Dublin) was broadcast by the Irish state television broadcaster RTÉ in May 2011. I am very grateful to him for making the documentary available to me.
}

\footnotetext{
${ }^{4}$ Also by Liam McGrath: Southpaw: The Francis Barrett Story (1999) and Unsettled: From Tinker to Traveller (2012). See: http://www.scratchfilms.com.

${ }^{5}$ Online comments to The Irish Times (O’Brien 2014). Available at www.irishtimes.com/news/social-affairs.
} 


\section{References}

Bhreatnach, Aoife. 2007. "Confusing Origins and Histories: The Case of Irish Travellers." Irish Journal of Anthropology 10(1): 30-5

Bolnick, Deborah A. 2008. "Individual Ancestry Inference and the Reification of Race as a Biological Phenomenon." In Revisiting Race in a Genomic Age, edited by Barbara A. Koenig, Sandra Soo-Jin Lee, and Sarah S. Richardson, 70-85. New Brunswick: Rutgers University Press.

Crawford M. H. and Gmelch George. 1974. "Human Biology of the Irish Tinkers:

Demography, Ethnohistory, and Genetics.” Biodemography and Social Biology 21(4): 321-231.

Crowley, Una M. 2005. "Liberal Rule Through Non-liberal Means: The Attempted Settlement of Irish Travellers (1995-1975).” Irish Geography 38(2): 128-150.

Crowley, Una and Rob Kitchin. 2007. "Paradoxical Spaces of Traveller Citizenship in Contemporary Ireland." Irish Geography 40(2): 128-145.

Equality Authority. 2006. Traveller Ethnicity: An Equality Authority Report. Dublin: The Equality Authority.

Fanning, Bryan. 2002. Racism and Social Change in the Republic of Ireland. Manchester: Manchester University Press.

Fanning, Bryan and Fidele Mutwarasibo, F. 2007. "Nationals/non-nationals: Immigration, Citizenship and Politics in the Republic of Ireland." Ethnic and Racial Studies 30(3): 439-460.

Fanning, Bryan. 2007. “Racism, Rules and Rights.” In Immigration and Social Change in the Republic of Ireland, edited by Bryan Fanning, 6-26. Manchester: Manchester University Press. 
Fanning, Bryan. 2008. New Guests of the Irish Nation. Dublin: Irish Academic Press.

Fujimura, Joan H., Deborah A. Bolnick, Ramya Rajagopalan, Jay S. Kaufman, Richard C. Lewontin, Troy Duster, Pilar Ossorio, Jonathan Marks

2014. "Clines Without Classes: How to Make Sense of Human Variation." Sociological Theory 32(3): 208-227.

Fullwiley Duana. 2007. "Race and Genetics: Attempts to Define the Relationship." BioSciences 2: 221-237.

Hall, Stuart. 2000. “Conclusion: The Multi-Cultural Question.” In Un/settled Multiculturalisms: Diaspora, Entanglements, Transruptions, edited by Barnor Hesse, 209-241. London: Zed Books.

Helleiner, Jane. 2000. Irish Travellers: Racism and the Politics of Culture. Toronto: University of Toronto Press.

Hinterberger, Amy. 2012. "Categorization, Census, and Multiculturalism: Molecular Politics and the Material of Nation", in Genetics and the Unsettled Past: The Collision of DNA, Race, and History, edited by Keith Wailoo, Alondra Nelson and Catherine Lee, 204-224. New Brunswick: Rutgers University Press.

Houses of the Oireachtas, Joint Committee on Justice, Defence and Equality, Report on the Recognition of Traveller Ethnicity, April 2014, Dublin.

Hughes, Freda, 2015. "Anti-Traveller Sentiment is the Last Bastion of a Backward Ireland." thejournal.ie, 5 November 2015. http://www.thejournal.ie/readme/travellerethnicity-2427545-Nov2015

Mac Laughlin, Jim. 1998. "The Political Geography of Anti-Traveller Racism in Ireland: The Politics of Exclusion and the Geography of Closure." Political Geography 17(4): 417-435. 
Mac Laughlin, Jim. 1999. "Nation-building, Social Closure and Anti-Traveller Racism in Ireland." Sociology 33(1): 129-151.

Marks, Jonathan. 2001. "We're Going to Tell These People Who They Really Are: Science and Relatedness." In Relative Values: Reconfiguring Kinship Studies, edited by Sarah Franklin and Susan McKinnon, 355-383. Berkeley: Duke University Press.

McVeigh, Robbie. 2007a. "“Ethnicity Denial' and Racism: The Case of the Government of Ireland Against Irish Travellers.” Translocations: The Irish Migration, Race and Social Transformation Review http://www.translocations.ie

McVeigh, Robbie. 2007b. “The 'Final Solution': Reformism, Ethnicity Denial and the Politics of Anti-Travellerism in Ireland." Social Policy and Society 7(1): 91-102.

Moore, Catherine. 2004. “Group Rights for Nomadic Minorities: Ireland's Traveller Community." The International Journal of Human Rights 8(2): 175-197.

Moore, R. G. 2012. “ 'Last Among Equals': Irish Travellers and Change in the $21^{\text {st }}$ Century.” Europäisches Journal für Minderheitenfragen 5(1): 27-40.

Mulcahy, Aogán. 2011. “ 'Alright in Their Own Place’: Policing and the Spatial Regulation of Irish Travellers.” Criminology and Criminal Justice 12(3): 307-327.

Mullally, Siobhán. 2007. “Children, Citizenship and Constitutional change.” In Immigration and Social Change in the Republic of Ireland, edited by Bryan Fanning, 27-46. Manchester: Manchester University Press.

Nash, Catherine. 2008. Of Irish Descent: Origin Stories, Genealogy and the Politics of Belonging. Syracuse: Syracuse University Press.

Nash, Catherine. 2014. "Blood of the Irish: Knowing 'Ourselves' Genetically." Irish Review 48: 1-16. 
Nash, Catherine. 2015. Genetic Geographies: The Trouble with Ancestry.

Minneapolis: Minnesota University Press.

Nelson, Alondra. 2016. The Social Life of DNA: Race, Reparations, and Reconciliation After the Genome. Boston: Beacon Press.

Nic Craith, Máiréad. 2002. Plural Identities - Singular Narratives: The Case of Northern Ireland. Oxford: Berghahn Books.

Ní Shuinéar, Sinéad. 1994. "Irish Travellers, Ethnicity and the Origins question.” In Irish Travellers: Culture and Ethnicity, edited by May McCann, Séamus Ó Síocháin and Joseph Ruane, 54-77. Belfast: Institute of Irish Studies.

Ní Shuinéar, Sinéad. 2004. "Apocrypha to Canon: Inventing Irish Traveller history." History Ireland 12(4): 15-19.

Norris, M. and Winston N. 2005. "Housing and Accommodation of Irish Travellers: From Assimilation to Multiculturalism and Back Again.” Social Policy and Administration 39(7): 802-821.

North Kari E., Lisa J. Martin and Michael H. Crawford. 2000. "The Origins of the Irish Travellers and the Genetic Structure of Ireland." Annals of Human Biology 27(5): 453-465.

Ó hAodha, Míchéal. ed. 2009. Travellers and Showpeople: Recovering Migrant History. Newcastle: Cambridge Scholars Publishing.

O’Brien, Car. 2014. “'Oireachtas Group Calls on State to Recognize Traveller Ethnicity." Irish Times, April 17.

O'Connell, R. 2006. “The Right to Participation of Minorities and Irish Travellers.” Studies in Ethnicity and Nationalism 6 (3): 2-30. 
O’Halloran, Marie. 2015. “Ó Ríordáin Hits Out at ‘Focus Group Equality’ Ahead of Dáil Vote." Irish Times, November 3.

Reardon, Jenny. 2007. "Democratic Mis-Haps: The Problem of Democratization in a Time of Biopolitics.” BioSocieties 2: 239-256.

Reardon, Jenny. 2012. "The Democratic, Anti-Racist Genome? Technoscience at the Limits of Liberalism." Science as Culture 21(1): 25-47.

Relethford John H. and Crawford Michael H. 2013. "Genetic Drift and the Population History of the Irish Travellers." American Journal of Physical Anthropology 150: 184-189.

Sheahan, Fionnan. 2014. "Fine Gael Chairman Dismisses Traveller Ethnic Group Call as Political Correctness." Irish Independent, April 18.

Sommer, Marianne. 2010. "DNA and Cultures of Remembrance: Anthropological Genetics, Biohistories and Biosocialities.” BioSocieties 5(3): 366-390, 369.

TallBear, Kimberly. 2013. Native American DNA: Tribal Belonging and the False Promise of Genetic Science. Minneapolis: Minnesota University Press.

Tong, P., J. G. Prendergast, A. J. Lohan, S. M. Farrongton, S. Cronin, N. Friel, D. G. Bradley, O. Hardiman, A. Evans, J. F. Wilson, B. Loftus. (2010) "Sequencing and Analysis of an Irish Human Genome.” Genome Biology 11(9): 1-14.

Walsh, Christine. 2009. Postcolonial Borderlands: Orality and Irish Travellers Writing. Newcastle: Cambridge Scholars Publishing.

Zerubavel, Eviatar. 2012. Ancestors and Relatives: Genealogy, Identity, and Community. Oxford: Oxford University Press. 